\title{
Soil attributes and coffee yield in an agroforestry system
}

\author{
Máximo Gerardo Ochoa Jácome ${ }^{1}$ (D), José Ricardo Mantovani ${ }^{1}$ (D), Adriano Bortolotti da Silva ${ }^{1}$ (D), \\ Tiago Teruel Rezende ${ }^{1}$ (D), Paulo Roberto Côrrea Landgraf ${ }^{1}$ (D)
}

${ }^{1}$ Universidade José do Rosário Vellano/Unifenas, Alfenas, MG, Brasil

Contact authors: max_ochoa2002@yahoo.com,mantovanijr@yahoo.com, adriano.silva@unifenas.br, tiago.rezende@unifenas.br, paulo.landgraf@unifenas.br Received in November 14, 2019 and approved in March 10, 2020

\begin{abstract}
Coffee growing in an agroforestry system may provide improvements in soil chemical and physical attributes, increase crop yield and diversify production. However, there are few studies on coffee growing intercropped with high quality wood-producing species such as African mahogany, teak and Australian cedar. The objective of this study was to evaluate, in an agroforestry system, the effect of coffee intercropping with tree species and the density of these species on chemical and physical soil attributes and on coffee yield. The experiment was carried out in Santo Antônio do Amparo, MG, and Catuaí Vermelho IAC 99 coffee was used in a $3.4 \times 0.7 \mathrm{~m}$ spacing. A randomized block design with split plots was used, with one additional treatment and 4 replications. The treatments consisted, in the plot, of three tree forest species: Australian cedar, teak and African mahogany, used intercropped with coffee; and, in the subplots, two densities of these forest species: 82 plants ha- 1 ( $13.6 \mathrm{~m}$ between rows and $9 \mathrm{~m}$ between plants) and 41 plants ha- 1 (13.6 $\mathrm{m}$ between rows and $18 \mathrm{~m}$ between plants). The additional treatment consisted of conventional coffee cultivation growing without intercropping with the tree species. At 64 months after the experiment was set, when the forest species were still under development, soil samples were taken at a depth of 0 to $0.1 \mathrm{~m}$ to determine the following chemical attributes: $\mathrm{pH}$ in $\mathrm{H}_{2} \mathrm{O}$, potential acidity, organic matter content, $\mathrm{P}-\mathrm{Mehlich}_{\mathrm{K}} \mathrm{K}^{+}, \mathrm{Ca}^{2+}, \mathrm{Mg}{ }^{2+}, \mathrm{S}, \mathrm{B}, \mathrm{Cu}, \mathrm{Fe}, \mathrm{Mn}, \mathrm{Zn}$ and base saturation (V\%); and physical soil attributes: bulk density, macroporosity, microporosity, total porosity. Soil temperature at $0.05 \mathrm{~m}$ depth and coffee yield were also evaluated. Chemical and physical attributes, besides soil temperature, are similarly influenced with the cultivation of Australian cedar, teak and African mahogany, intercropped with coffee, in both densities, 82 and 41 plants ha ${ }^{-1}$, after 5 years of implementation of the agroforestry system. Coffee cultivation in agroforestry system with Australian cedar, teak and African mahogany increases the organic matter and $\mathrm{P}$ content of the soil, but acidifies the soil and does not influence its physical attributes. The agroforestry system with teak and African mahogany increases coffee yield.
\end{abstract}

Key words: Coffea arabica; Intercropping; Shading; Soil fertility.

\section{INTRODUCTION}

Coffee is the most popular and most consumed beverage in the world (Souza et al., 2017). Brazil is the world's leading coffee producer and exporter and, in the country, coffee is predominantly grown in monoculture (Morinigo et al., 2017; Souza et al., 2017; Conab, 2019) However, it is very common in some producing regions of the world, such as Colombia and Central American countries, to grow shaded coffee trees, as a function of the origin of the coffee tree in moderately shaded understory environments, and once the crop is not tolerant to high temperatures (JaramilloBotero; Martinez; Santos, 2006; Valentini et al., 2010).

Agroforestry systems are characterized by the use of woody tree species in association with agricultural crops, simultaneously or alternately in time and space (Magalhães et al., 2013; Melloni et al., 2018). In agroforestry systems, tree species can make microclimate conditions more suitable for coffee, and increase crop yield; provide greater input of plant residues on the soil surface, which may contribute to greater soil protection and decreased erosion losses; increased organic matter content and soil fertility, in addition to improved soil physical quality (Carmo et al., 2014; Guimarães et al., 2014; Araújo et al., 2015; Souza et al., 2017).

Agroforestry systems can also decrease the impact of climate change and global warming on coffee crops; minimize crop exposure to adverse weather events such as frost and excessive winds; enable the cultivation of coffee in areas with climatic conditions marginal to the crop; and provide farmers with additional income by exploiting the species used intercropped with the coffee tree by selling wood, fruits and essential oils, among others (Coelho et al., 2010; Pezzopane et al., 2010; Pinto Neto et al., 2014). However, depending on the species and spacing used in the agroforestry system, coffee yield may decrease due to excessive shading (JaramilloBotero; Martinez; Santos, 2006; Araújo et al., 2016).

In Brazil, several species have been used intercropped with coffee, in agroforestry systems, such as inga (Inga vera Willd), silver oak (Grevillea robusta A. Cunn) (Salgado et al., 2006) rubber tree (Hevea brasiliensis L.) (Partelli et al., 2014), peach palm (Bactris gasipae) (Souza et al., 2017), besides fruit such as macadamia (Macadamia integrifolia) (Pezzopane et al., 2010), dwarf coconut (Cocus nucifera L.) (Valentini et al., 2010) and banana (Araújo et al., 2015).

Australian cedar (Toona ciliata M. Roem var. australis), teak (Tectona grandis L.f.) and African mahogany (Khaya ivorensis A. Chev.) are tree species that have excellent quality wood and commercial value (Braga; Furtini Neto; Oliveira, 2015; Garcia; Marinonio, 2016; Ribeiro; Ferraz Filho; Scolforo, 2017), The use of these tree species intercropped with coffee, in an agroforestry system, can provide soil, economic and environmental benefits, but coffee intercropping with these species is still poorly studied. 
Given the above, the objective of this study was to evaluate, in an agroforestry system, the effect of coffee intercropped with tree species and the density of these species on soil chemical and physical attributes, besides coffee yield.

\section{MATERIAL AND METHODS}

The experiment was conducted in the field on Fazenda da Lagoa (latitude $20^{\circ} 55^{\prime}$ 3" $\mathrm{S}$ and longitude 44 $51^{\prime}$ 4" $\mathrm{W}$, altitude $1095 \mathrm{~m}$ ), located in Santo Antônio do Amparo, MG.

The area under study in the agroforestry system (AFS) was implanted in December 2012, in an Oxisol, with the transplantation of Catuaí Vermelho IAC 99 coffee at a spacing of $3.4 \times 0.70 \mathrm{~m}$, and of forest tree species. The monthly average values of minimum temperature, maximum temperature and rainfall during the experimental period (December 2012 to June 2018) are presented in Figure 1, and the average temperature variable was 12 to $28^{\circ} \mathrm{C}$.

A randomized block design with split plots, an additional treatment and 4 replications was used. The treatments consisted of three tree species: Australian cedar (Toona ciliata M. Roem var. australis), teak (Tectona grandis L.f.) and African mahogany (Khaya ivorensis A. Chev.), used intercropped with coffee; and, in the subplots, two densities of these forest species: 82 plants ha ${ }^{-1}(13.6 \mathrm{~m}$ between rows and $9 \mathrm{~m}$ between plants) and 41 plants $\mathrm{ha}^{-1}(13.6 \mathrm{~m}$ between rows and $18 \mathrm{~m}$ between plants). The additional treatment consisted of conventional coffee cultivation, without intercropping with the tree species. Thus, the experiment consisted of 28 plots.

For the coffee tree in AFS, there was one tree species row, according to the treatments, every 4 coffee rows. The subplots with a density of 41 plants ha-1 measured $27.2 \times 36 \mathrm{~m}$ $\left(979.2 \mathrm{~m}^{2}\right)$, and consisted of two rows of the forest species and 8 coffee rows, with 48 plants per row (384 coffee plants) (Figure 2 ). The subplots with a density of 82 plants $\mathrm{ha}^{-1}$ and the smallest plant spacing of the forest species were $27.2 \times 18 \mathrm{~m}\left(489.6 \mathrm{~m}^{2}\right)$, had two rows of the forest species and 8 coffee rows, with 24 plants per row (192 coffee plants).

The useful area of each subplot was $10.2 \times 5.6 \mathrm{~m}\left(57.1 \mathrm{~m}^{2}\right)$, and consisted of the tree species arranged in the center of the useful area surrounded by 24 coffee plants ( 3 central rows and 8 plants per row). Evaluations of soil attributes and parameters of coffee plants were carried out in the useful area of each subplot.

At 58, 60 and 62 months after the implementation of the experiment, from October 2017 to February 2018, soil temperature was evaluated at $0.05 \mathrm{~m}$ depth in the coffee canopy projection at three randomly taken points, between 3 and 4 p.m., using a soil thermometer.

At 64 months after the experiment was set, in April 2018, soil sampling was performed in the coffee canopy projection, at a depth of 0 to $0.1 \mathrm{~m}$, using a probe. The composite sample from each subplot was obtained by collecting and mixing 15 simple samples. In soil samples, the chemical attributes $\mathrm{pH}$ in $\mathrm{H}_{2} \mathrm{O}$, potential acidity $(\mathrm{H}+\mathrm{Al})$, organic matter contents, P-Mehlich, $\mathrm{K}^{+}, \mathrm{Ca}^{2+}, \mathrm{Mg}^{2+}, \mathrm{S}, \mathrm{B}, \mathrm{Cu}, \mathrm{Fe}, \mathrm{Mn}, \mathrm{Zn}$ and base saturation (V\%) were determined (Silva, 2009).

Subsequently, undisturbed samples were collected at a depth of 0 to $0.1 \mathrm{~mm}$, using a $100 \mathrm{~cm}^{3}$ volumetric ring. In each subplot, three undisturbed soil samples were collected in the coffee canopy projection and three between rows. In these samples, the physical attributes soil bulk density, macroporosity, microporosity and total porosity were determined (Donagema, 2011).

Coffee harvest was carried out in June 2018, 67 months after the experiment was set, by hand melting of the fruits of the useful area of each subplot. The coffee was then dried in in the field, to $12 \%$ of humidity; subsequently, it was processed for the obtention of yield, in bags ha-1.

The results of soil chemical and physical attributes, in addition to temperature, plant height and coffee yield were submitted to analysis of variance by the F test, Tukey test, at 5\% probability, using the Agroestat software (Barbosa; Maldonado Junior, 2015). The comparison between the

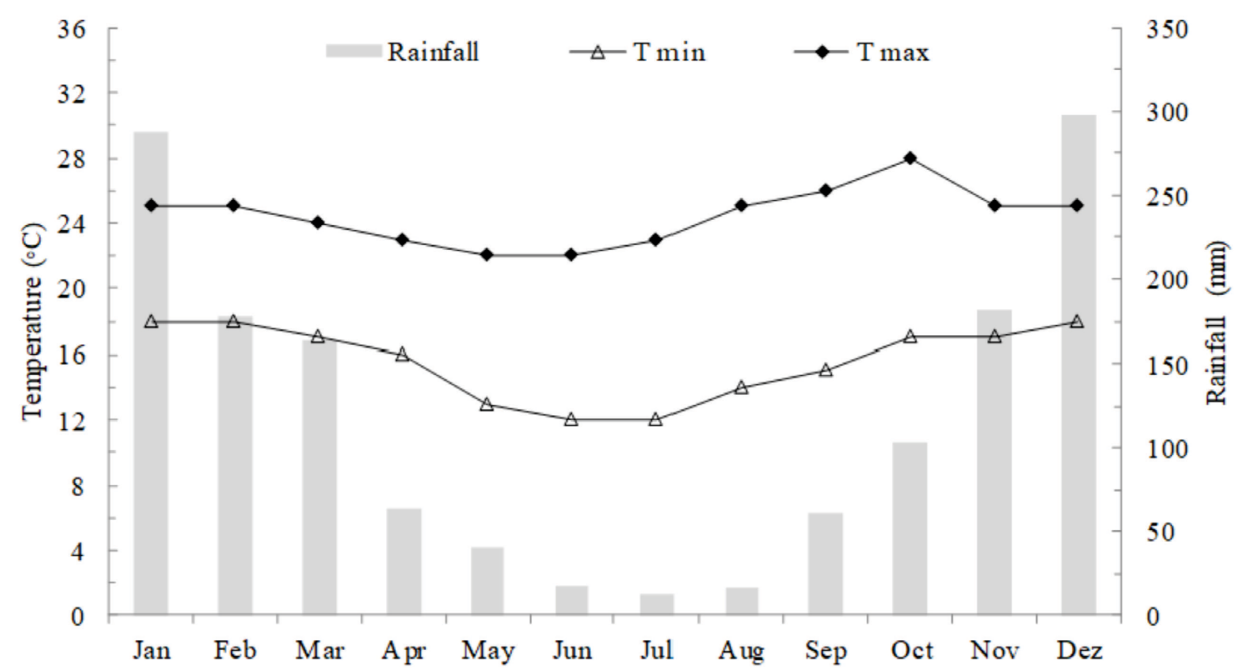

Figure 1: Air temperature and rainfall during the experimental period. Santo Antônio do Amparo-MG, 2012 to 2018. 


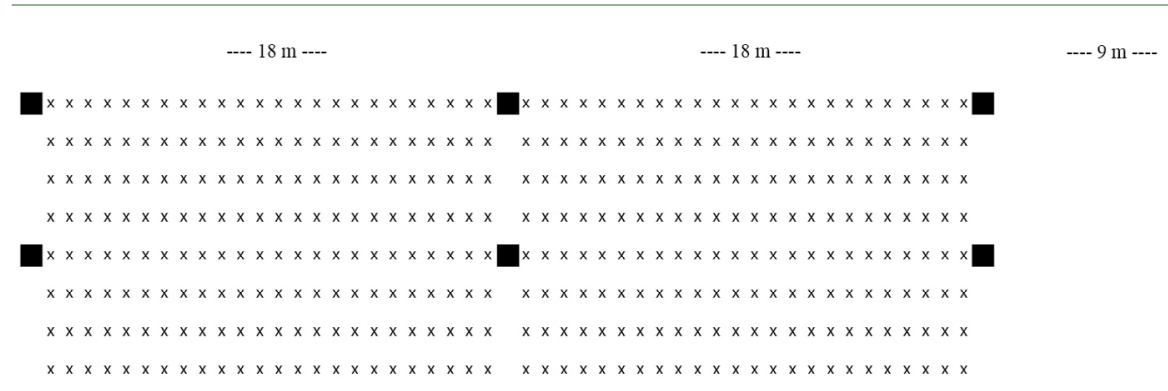

Density 1: 41 plants ha-1

Figure 2: Representation of the experiment subplots.

treatments in the agroforestry system and the additional treatment was performed by unfolding the degrees of freedom of the treatments by the contrast method.

\section{RESULTS AND DISCUSSION}

The soil chemical attributes evaluated in the $0-0.1 \mathrm{~m}$ layer, with the exception of organic matter, did not change ( $>0.05$ ), after 64 months of the implementation of the experiment, when comparing the tree species and planting densities used in the agroforestry system (Tables 1 and 2).

It was also verified that there was a significant difference $(\mathrm{p}<0.01)$ in acidity ( $\mathrm{pH}$ and $\mathrm{H}+\mathrm{Al}$ values) and soil organic matter and $\mathrm{P}$ contents, at $0-0.1 \mathrm{~m}$ depth, when comparing the mean values of treatments in the agroforestry system with the additional treatment (conventional coffee cultivation). The other soil chemical attributes evaluated $\left(\mathrm{K}^{+}, \mathrm{Ca}^{2+}, \mathrm{Mg}^{2+}, \mathrm{S}, \mathrm{B}\right.$, $\mathrm{Cu}, \mathrm{Fe}, \mathrm{Mn}$ and $\mathrm{Zn}$ contents and base saturation) did not differ ( $p>0.05)$ between the evaluated cultivation systems. The good soil fertility conditions of the experimental area and the slow growth of the tree species used possibly explain these results.

The mean values obtained in the agroforestry system for soil chemical attributes were 5.9 (good); $3.8 \mathrm{cmol} \mathrm{dm}^{-3}$ (medium); 71 (very good) and $138 \mathrm{mg} \mathrm{dm}^{-3}$ (very good); 4.9 (very good) and $1.2 \mathrm{cmol}_{\mathrm{c}} \mathrm{dm}^{-3}$ (good); 72\% (good); 25 (very good); 0.35 (medium); 4.5 (high); 44 (good); 13 (high); $3 \mathrm{mg} \mathrm{dm}^{-3}$ (high), respectively, for $\mathrm{pH}$ in $\mathrm{H}_{2} \mathrm{O}, \mathrm{H}+\mathrm{Al}$, P-Mehlich, $\mathrm{K}^{+}, \mathrm{Ca}^{2+}, \mathrm{Mg}^{2+}$, base saturation, $\mathrm{S}, \mathrm{B}$, and metallic micronutrients $\mathrm{Cu}, \mathrm{Fe}, \mathrm{Mn}$ and $\mathrm{Zn}$, and CFSEMG (1999) interpretation classes were used.

Similar results were obtained by Salgado et al. (2006), who found that the soil chemical attributes at a depth of $0-0.2$ $\mathrm{m}$ were little changed when comparing the coffee crop in AFS intercropped with inga for 15 years; with silver oak for 9 years; and conventional cultivation. In contrast, Carmo et al. (2014) found higher levels of $\mathrm{Ca}^{2+}, \mathrm{Mg}^{2+}$, organic matter and base saturation, and lower levels of $\mathrm{P}, \mathrm{H}+\mathrm{Al}$ and $\mathrm{Al}^{3+}$ in the soil at $0-0.2 \mathrm{~m}$ depth in coffee plantation in AFS intercropped with native trees, banana and eucalyptus, compared to the conventional cultivation. The authors found no difference in soil $\mathrm{K}^{+}$content in the evaluated cropping systems.

Morinigo et al. (2017) found, in shaded coffee cultivation, that the spatial distribution of Fabaceae (Anadenanthera falcata, Albizia polycephala and Cassia grandis) trees, located 1 and 6 meters away from the coffee tree, did not alter soil chemical attributes, organic matter, $\mathrm{P}, \mathrm{K}$ and $\mathrm{Ca}$, at a depth of $0-0.2 \mathrm{~m}$.

There was a significant interaction of tree species and plant densities used in the agroforestry system in relation to soil organic matter contents (Table 3). At a density of 82 plants ha ${ }^{-1}$, it was found that the intercropping of Australian cedar and coffee yielded an increase of $14 \%$ in the soil organic matter content, compared to coffee intercropped with teak and African mahogany. However, at a density of 41 plants $\mathrm{ha}^{-1}$, there was no difference $(p>0.05)$ in the soil organic matter content as a function of the tree species used. These results can be explained by the greater contribution of plant residues to the soil by Australian cedar in relation to teak and African mahogany, particularly with the use of higher plant densities.

It was also found for Australian cedar that the higher density of plants provided an increase in soil organic matter content of $24 \%$, compared to lower densities. However, for teak and African mahogany, plant density did not influence ( $p$ $>0.05$ ) the soil organic matter content (Table 3).

Higher soil acidity was observed in coffee plants in AFS than in conventional cultivation and, in AFS, the soil $\mathrm{pH}$ in $\mathrm{H}_{2} \mathrm{O}$ was 0.6 units lower and potential acidity was $31 \%$ higher (Figures $3 \mathrm{~A}$ and $3 \mathrm{~B}$ ). It was also verified that the organic matter and soil $P$ contents in AFS were, respectively, 16 and 20\% higher than in the convencional coffee cultivation (Figures $3 \mathrm{C}$ and $3 \mathrm{D}$ ).

It was expected that, in AFS, soil acidity would be lower than in conventional cultivation due to the larger amount of plant residues deposited on the soil surface, and the $\mathrm{H}^{+}$ consumption of the soil solution by released water-soluble organic compounds by these plant residues (Pavan et al., 1999). According to these authors, the plant residues contain water-soluble organic anions ( $\mathrm{R}_{-} \mathrm{COO}^{-}$and $\mathrm{R}^{-} \mathrm{O}^{-}$) which, when released, can adsorb $\mathrm{H}^{+}$from the soil solution by an exchange involving mainly $\mathrm{Ca}^{2+}$, increasing soil $\mathrm{pH}$. 
Table 1: Analysis of variance of soil chemical attributes: $\mathrm{pH}$, potential acidity $(\mathrm{H}+\mathrm{Al})$, organic matter $(\mathrm{MO}), \mathrm{P}, \mathrm{K}, \mathrm{Ca}$ and $\mathrm{Mg}$ contents, at $0-0.1 \mathrm{~m}$ depth, as a function of the treatments used.

\begin{tabular}{|c|c|c|c|c|c|c|c|}
\hline \multirow{2}{*}{$\begin{array}{l}\text { Causes of } \\
\text { Variation }\end{array}$} & \multicolumn{7}{|c|}{ F values } \\
\hline & $\mathrm{pH}$ & $\mathrm{H}+\mathrm{Al}$ & MO & $P$ & $\mathrm{~K}$ & $\mathrm{Ca}$ & $\mathrm{Mg}$ \\
\hline Forest species (S) & $1.21^{\mathrm{NS}}$ & $1.97^{\mathrm{NS}}$ & $5.30 *$ & $4.01^{\mathrm{NS}}$ & $4.17^{\mathrm{NS}}$ & $0.17^{\mathrm{NS}}$ & $0.35^{\mathrm{NS}}$ \\
\hline Densities (D) & $0.43^{\mathrm{NS}}$ & $0.41^{\mathrm{NS}}$ & $41.51 * *$ & $0.15^{\mathrm{NS}}$ & $2.84^{\mathrm{NS}}$ & $0.06^{\mathrm{NS}}$ & $1.97^{\mathrm{NS}}$ \\
\hline SxD & $3.44^{\mathrm{NS}}$ & $3.08^{\mathrm{NS}}$ & $34.22 * *$ & $0.07^{\mathrm{NS}}$ & $3.39^{\mathrm{NS}}$ & $3.77^{\mathrm{NS}}$ & $1.28^{\mathrm{NS}}$ \\
\hline AFS x Conventional system & $11.10 * *$ & $5.59 *$ & $6.81 *$ & $7.28 *$ & $0.12^{\mathrm{NS}}$ & $2.05^{\mathrm{NS}}$ & $1.38^{\mathrm{NS}}$ \\
\hline $\mathrm{CV}(\%)$ for $\mathrm{S}$ & 7.34 & 20.69 & 10.89 & 15.83 & 15.79 & 18.50 & 20.13 \\
\hline $\mathrm{CV}(\%)$ for $\mathrm{D}$ & 4.72 & 14.18 & 5.48 & 19.18 & 9.33 & 15.50 & 17.31 \\
\hline
\end{tabular}

${ }^{*},{ }^{* *}$ and ${ }^{\mathrm{NS}}$ correspond to significant $\mathrm{p}<0.05$ and $\mathrm{p}<0.01$ and not significant, respectively.

Table 2: Analysis of variance of soil chemical attributes: base saturation (V), and S, B, Cu, Fe, Mn and $\mathrm{Zn}$ contents, at $0-0.1 \mathrm{~m}$ depth, as a function of the treatments used.

\begin{tabular}{cccccccc}
\hline \multirow{2}{*}{$\begin{array}{c}\text { Causes of } \\
\text { Variation }\end{array}$} & \multicolumn{3}{c}{ F values } \\
\cline { 2 - 8 } & $\mathrm{V}$ & $\mathrm{S}$ & $\mathrm{B}$ & $\mathrm{Cu}$ & $\mathrm{Fe}$ & $\mathrm{Mn}$ & $\mathrm{Zn}$ \\
\hline Forest species (S) & $0.75^{\mathrm{NS}}$ & $0.70^{\mathrm{NS}}$ & $1.17^{\mathrm{NS}}$ & $0.98^{\mathrm{NS}}$ & $0.28^{\mathrm{NS}}$ & $1.34^{\mathrm{NS}}$ & $2.57^{\mathrm{NS}}$ \\
Densities (D) & $0.01^{\mathrm{NS}}$ & $0.93^{\mathrm{NS}}$ & $0.96^{\mathrm{NS}}$ & $0.31^{\mathrm{NS}}$ & $3.28^{\mathrm{NS}}$ & $0.06^{\mathrm{NS}}$ & $0.74^{\mathrm{NS}}$ \\
SxD & $2.72^{\mathrm{NS}}$ & $0.63^{\mathrm{NS}}$ & $1.20^{\mathrm{NS}}$ & $2.07^{\mathrm{NS}}$ & $2.52^{\mathrm{NS}}$ & $2.08^{\mathrm{NS}}$ & $1.80^{\mathrm{NS}}$ \\
\hline AFS x Conventional system & $3.74^{\mathrm{NS}}$ & $3.98^{\mathrm{NS}}$ & $1.27^{\mathrm{NS}}$ & $0.12^{\mathrm{NS}}$ & $0.83^{\mathrm{NS}}$ & $0.05^{\mathrm{NS}}$ & $1.44^{\mathrm{NS}}$ \\
\hline CV (\%) for E & 10.90 & 19.08 & 23.68 & 16.28 & 17.95 & 13.16 & 15.07 \\
CV (\%) for D & 5.63 & 21.14 & 10.15 & 18.88 & 10.99 & 15.78 & 18.50 \\
\hline
\end{tabular}

${ }^{\mathrm{NS}}$ correspond to not significant.

Table 3: Organic matter contents in the soil, at $0-0.1 \mathrm{~m}$ depth, in an agroforestry system, as a function of the treatments used.

\begin{tabular}{cccc}
\hline \multirow{2}{*}{ Densities } & \multicolumn{3}{c}{ Forest species } \\
\cline { 2 - 4 } & Australian ceder & Teak & African mahogany \\
\hline 82 plants ha $^{-1}$ & $41 \mathrm{Aa}$ & $34 \mathrm{Ba}$ & $37 \mathrm{Ba}$ \\
41 plants ha $^{-1}$ & $33 \mathrm{Ab}$ & $34 \mathrm{Aa}$ & $36 \mathrm{Aa}$ \\
\hline
\end{tabular}

Means followed by the same uppercase letter in the row and lowercase in the column do not differ by the Tukey test $(p>0,05)$.

The higher soil acidification in AFS can possibly be explained by the larger number of plants and, consequently, of roots in this system, compared to conventional coffee cultivation, which provided higher cation absorption by plants, and release of $\mathrm{H}^{+}$ions in the rhizosphere. to maintain the electroneutrality of the environment, which contributed to the increase soil acidity in AFS (Cruz et al., 2009).

The higher soil $\mathrm{P}$ content in AFS is related to the increase in soil organic matter content in this system, compared to conventional coffee cultivation. Thus, there is greater release of organic compounds, which compete with $\mathrm{P}$ for the same adsorption sites, which decreases the specific $\mathrm{P}$ adsorption in the soil, and increases nutrient availability (Guarçoni, 2011). According to this author, the formation of stable organometallic complexes with $\mathrm{Fe}$ and $\mathrm{Al}$ ions, in the presence of higher soil organic matter contents, can decrease $\mathrm{P}$ precipitation, and thus increase $\mathrm{P}$ availability.

Another possibility is that in AFS, due to the greater shading and increase in soil organic matter content, there is a greater formation of mycorrhizae in coffee, which favors P solubilization (Melloni et al., 2018). Increases in soil organic matter content with coffee growing in AFS were also obtained by Guimarães et al. (2014) and by Melloni et al. (2018).

In the agroforestry system, the treatments used (tree species and density of these species) did not change $(\mathrm{p}>0.05)$ soil physical attributes, evaluated at $0-0.1 \mathrm{~m}$ depth, bulk density, macroporosity, microporosity and total porosity (Table 4). There was also no difference in these soil physical attributes, when comparing the cultivation of coffee in agroforestry with the conventional cultivation. The mean values obtained in the experimental area of bulk density, macroporosity, microporosity and total porosity were $1.10 \mathrm{~g} \mathrm{~cm}^{-3} ; 34 ; 26$ and $60 \%$, respectively. 
A.

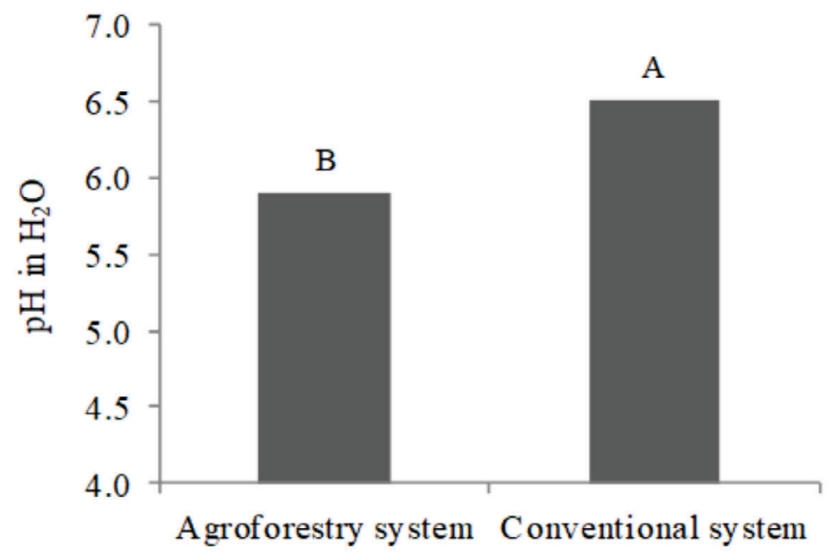

C.

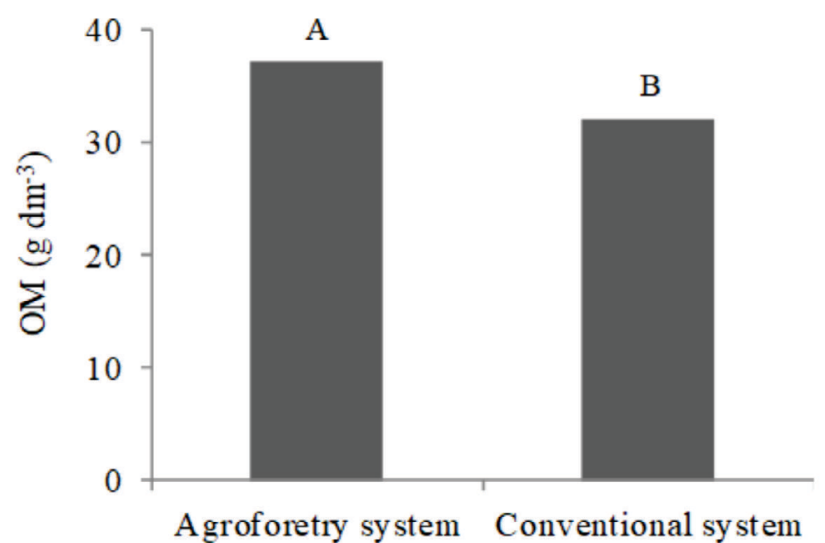

B.

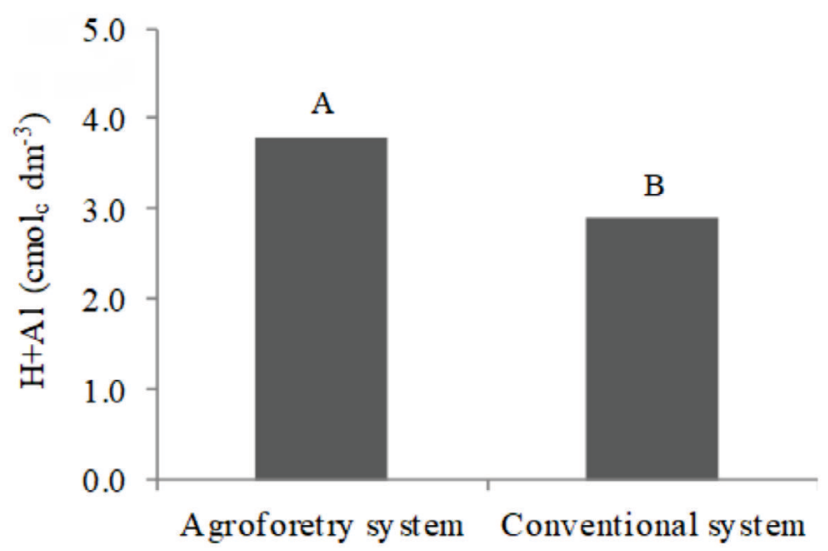

D.

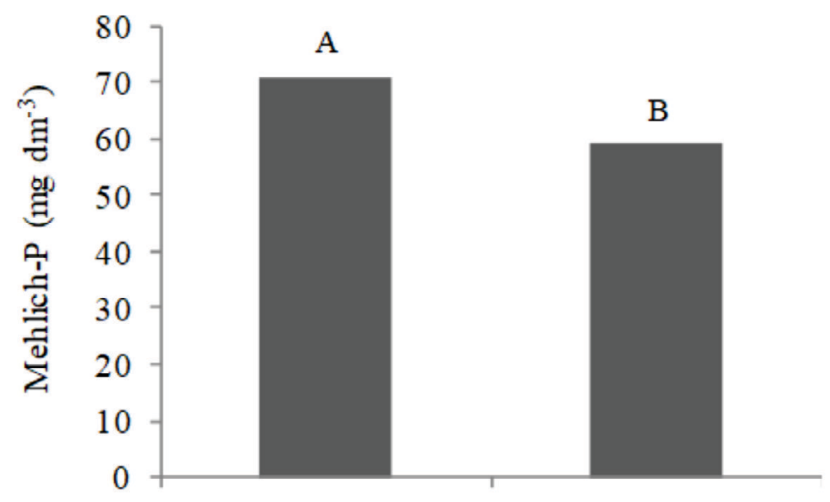

Agroforetry system Conventional system Figure 3: Values of $\mathrm{pH}$ in $\mathrm{H}_{2} \mathrm{O}(\mathrm{A})$, potential acidity $(\mathrm{H}+\mathrm{Al})(\mathrm{B})$ and contents of organic matter $(\mathrm{OM})(\mathrm{C})$ and available $\mathrm{P}(\mathrm{D})$ at a depth of $0-0.1 \mathrm{~m}$ soil, for coffee trees in an agroforestry system and conventional system. Santo Antônio do Amparo-MG, 2018. Same letter do not differ by the Tukey test $(p>0,05)$.

Table 4: Analysis of variance of soil physical attributes: bulk density (Bd), macroporosity (Pmacro), microporosity (Pmicro), total porosity (TP), at 0-0.1m depth, soil temperature $(T)$ as a function of the treatments used.

\begin{tabular}{|c|c|c|c|c|c|}
\hline \multirow{2}{*}{$\begin{array}{l}\text { Causes of } \\
\text { variation }\end{array}$} & \multicolumn{5}{|c|}{$\mathrm{F}$ values } \\
\hline & $\mathrm{Bd}$ & Pmacro & Pmicro & TP & $\mathrm{T}^{1}$ \\
\hline Forest species (S) & $0.51^{\mathrm{NS}}$ & $0.11^{\mathrm{NS}}$ & $4.49^{\mathrm{NS}}$ & $2.00^{\mathrm{NS}}$ & $3.58^{\mathrm{NS}}$ \\
\hline Densities (D) & $0.46^{\mathrm{NS}}$ & $4.60^{\mathrm{NS}}$ & $1.69^{\mathrm{NS}}$ & $3.22^{\mathrm{NS}}$ & $0.43^{\mathrm{NS}}$ \\
\hline SxD & $0.07^{\mathrm{NS}}$ & $0.97^{\mathrm{NS}}$ & $0.84^{\mathrm{NS}}$ & $0.87^{\mathrm{NS}}$ & $0,33^{\mathrm{NS}}$ \\
\hline AFS $x$ Conventional system & $1.74^{\mathrm{NS}}$ & $1.81^{\mathrm{NS}}$ & $1.82^{\mathrm{NS}}$ & $2.44^{\mathrm{NS}}$ & $59.02^{\star *}$ \\
\hline CV (\%) for S & 4.62 & 4.30 & 2.37 & 2.98 & 1.15 \\
\hline CV $(\%)$ for $D$ & 4.09 & 7.70 & 7.35 & 2.39 & 0.74 \\
\hline
\end{tabular}

${ }^{1}$ averages of three evaluations, ${ }^{* *}$ and ${ }^{\mathrm{NS}}$ correspond to significant $p<0.01$ and not significant, respectively.

Similar results were obtained by Carmo et al. (2014), who also found no differences in soil physical attributes bulk density, macroporosity, microporosity and total porosity between agroforestry and conventional coffee management systems. These authors justified the lack of response in the physical attributes to the fact that there was no soil revolving since the coffee plantation in the experimental area. Guimarães et al. (2014) also found no differences in soil density, macroporosity, microporosity and total porosity in cedar intercropped with organic coffee and conventional coffee cultivation. 
Souza et al. (2017) found, 27 months after the implantation of the coffee tree in an agroforestry system, that coffee intercropping with peach palm and gliricidia (Gliricidia sepium) resulted in improved soil physical quality due to lower soil bulk density values and higher values of microporosity and total porosity in relation to monoculture (conventional coffee cultivation). However, coffee intercropping with banana and ingá did not alter the soil physical attributes evaluated: bulk density, macroporosity, microporosity and total porosity in relation to conventional coffee cultivation.

The soil temperature at $0.05 \mathrm{~m}$ depth in the agroforestry system did not change $(p>0.05)$ with the treatments (species and plant density), and the average value was $21.2{ }^{\circ} \mathrm{C}$ (Table 4). However, soil temperature in conventional coffee cultivation was on average $1.4^{\circ} \mathrm{C}$, higher than in the agroforestry system, considering the three evaluations performed (Figure 4). This shows that the tree species used in AFS, Australian cedar, teak and African mahogany, were already shading the coffee tree about 5 years after the implementation of the experiment.

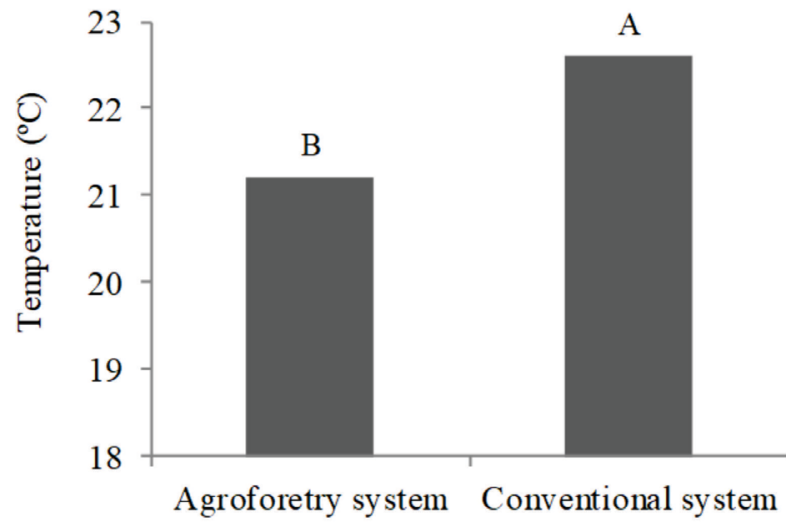

Figure 4: Soil temperature, at $0.05 \mathrm{~m}$ depth, for coffee trees in an agroforestry system and conventional cultivation. Santo Antônio do Amparo-MG, 2018.

Same letter do not differ by the Tukey test $(p>0,05)$.

Souza et al. (2017) obtained lower soil temperatures, at a depth of $0-0.1 \mathrm{~m}$, in peach palm intercropped with coffee and higher temperatures in coffee intercropped with banan and inga, when compared to conventional coffee cultivation.

In the agroforestry system, coffee yield varied according to the tree species used (Table 5). However, plant density did not influence $(\mathrm{p}>0.05)$ coffee yield, and there was no interaction between the factors studied in the agroforestry system (species and plant density) on coffee yield. There was a significant difference in coffee yield in the agroforestry system, particularly with the intercropping with teak and African mahogany, compared to conventional cultivation.

Coffee yield intercropped with teak was higher ( $\mathrm{p}$ $<0.05)$ than that obtained with Australian cedar cultivation (Figure 5). In the first condition, coffee yield was 73.1 bags ha $^{-1}$ and, in the second, it was 61.7 bags ha $^{-1}$, which corresponded to an increase of $18 \%$. Coffee yield in intercropping with African mahogany did not differ $(\mathrm{p}>0.05)$ from the yields obtained with the other two forest species.

Table 5: Analysis of variance of coffee yield, as a function of the treatments used.

\begin{tabular}{cc}
\hline Causes of Variation & F values \\
\hline Forest species (S) & $9.85^{*}$ \\
Densities (D) & $1.59^{\mathrm{NS}}$ \\
SxD & $0.09^{\mathrm{NS}}$ \\
AFS x Conventional system & $8.90^{* *}$ \\
Coffee tree-Cedar x Conventional system & $1.01^{\mathrm{NS}}$ \\
Coffee tree-Teak x Conventional system & $11.74^{* *}$ \\
Coffee tree-Mahogany x Conventional system & $4.37^{*}$ \\
CV (\%) for S & 7.79 \\
CV (\%) for D & 11.72 \\
\hline
\end{tabular}

*, ** and ${ }^{\mathrm{NS}}$ correspond to significantp $<0.05$ and $p<0.01$ and not significant, respectively.

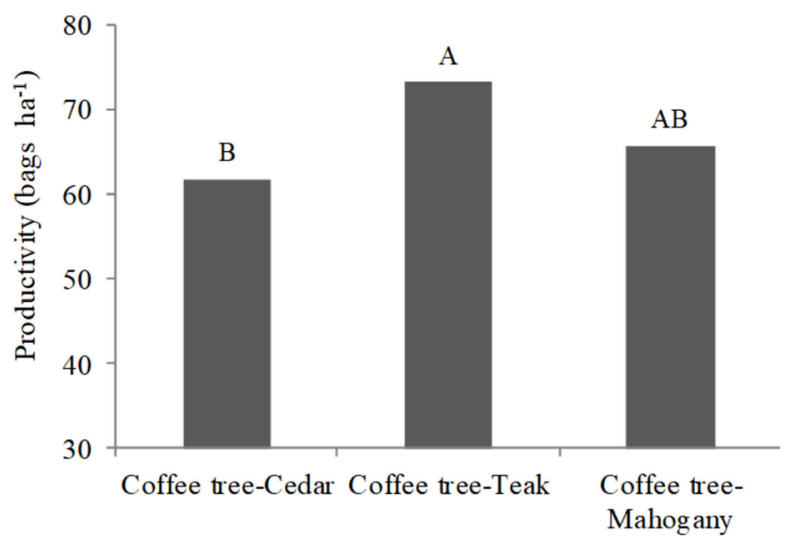

Figure 5: Coffee yield in an agroforestry system with Australian cedar, teak and African mahogany. Santo Antônio do AmparoMG, 2018.

Same letter do not differ by the Tukey test $(p>0,05)$.

Considering the three tree species used, the mean coffee yield in the agroforestry system was $15 \%$ higher than in conventional cultivation (Figure 6A). It was also found that the yields of coffee intercropped with teak and African mahogany were 26 and $13 \%$ higher, respectively, than in conventional cultivation (Figures 6C and 6D). Regarding coffee intercropped with Australian cedar, there was no difference $(p>0.05)$ in yield compared to conventional cultivation (Figure 6B).

After 5 years of implementation of the agroforestry system, higher increases in coffee yield were found than improvements in soil chemical and physical attributes. This increase in coffee yield in intercropping may possibly be explained by higher soil moisture and altered microclimate due to crop shading, especially with teak and African mahogany. 
A.

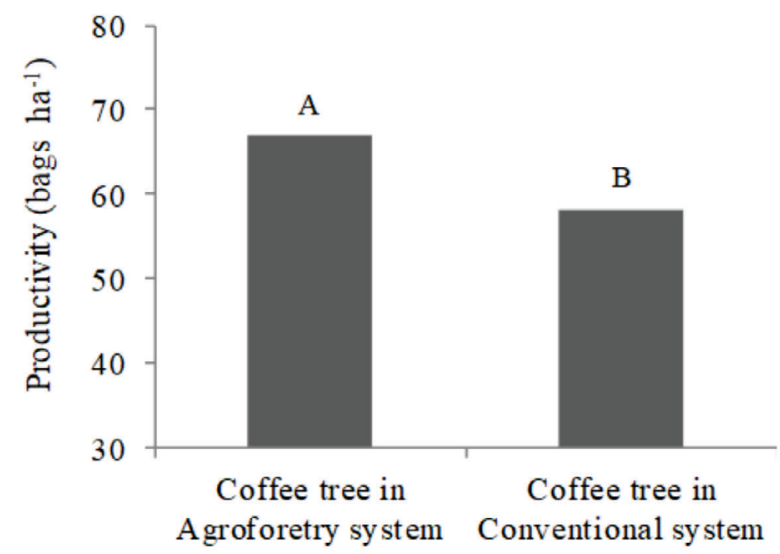

C.

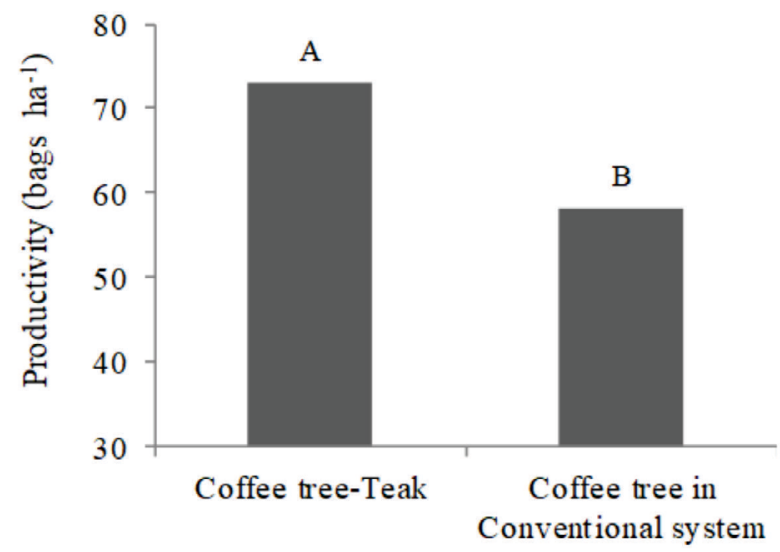

B.

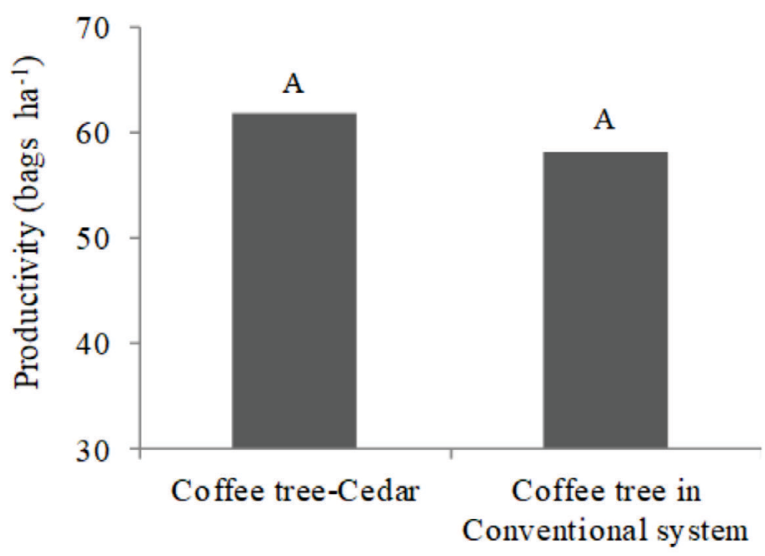

D.

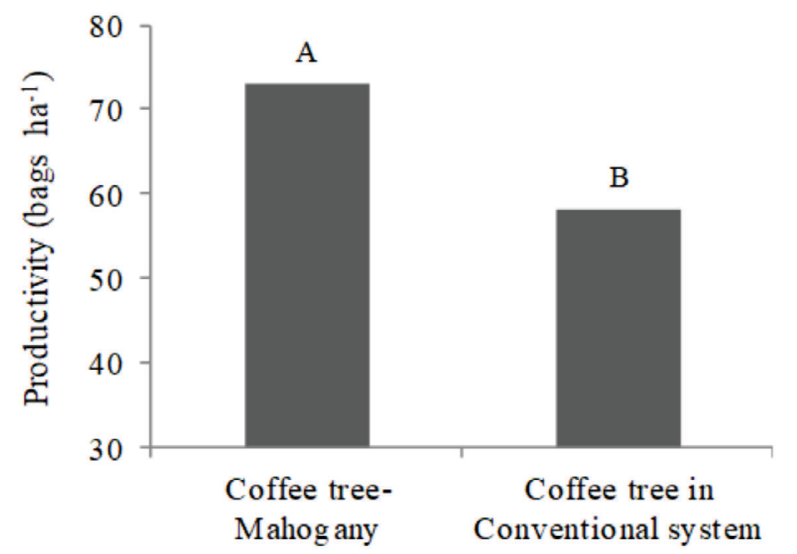

Figure 6: Coffee yield in agroforestry system and conventional cultivation. Santo Antônio do Amparo-MG, 2018.

Same letter do not differ by the Tukey test $(p>0,05)$.

The main effects of shading on coffee physiology are associated with the decrease in wind speed; in temperature variations; increase in relative air humidity, which results in greater stomatal opening, favoring $\mathrm{CO}_{2}$ uptake and photosynthetic rate. In addition, shading the coffee tree provides lower incidence of radiation, reducing photooxidative damage, which is frequently observed in coffee trees grown in areas with marginal crop climate (Da Mata; Ramalho, 2006).

According to Coelho et al. (2010), a decrease in light incidence between 23 and $38 \%$, due to shading, favor coffee production and, from $50 \%$, it impairs crop production.

Pinto Neto et al. (2014) in a coffee area planted with araucaria, with three shading levels: intense; medium and without shading, found a direct relationship between the reduction in light efficiency, measured by photosynthetically active radiation, and coffee shading by Araucaria trees.

Partelli et al. (2014) observed, in cultivation of coffee intercropped with rubber tree, changes in microclimate conditions of coffee trees close to the rubber tree, having occurred in air temperature and photosynthetically active radiation, and increase in relative humidity. According to the authors, coffee intercropped with the rubber tree did not affect coffee yield.

Araújo et al. (2015) verified, in coffee intercropped with banana, changes in the microclimate, due to the lower incidence of photosynthetically active radiation and air temperature throughout the day, especially in summer, due to coffee shading.

Considering that the tree species used in the experiment are slow growing, and that the implementation time of the agroforestry system was five years, the differences in yield and soil attributes will probably be intensified over the years between agroforestry and conventional cultivation, due to the increase in shading and the input of plant residues on the soil surface.

\section{CONCLUSIONS}

Soil chemical and physical attributes, as well as temperature, are similarly influenced with the cultivation of Australian cedar, teak and African mahogany, intercropped with the coffee tree, both at densities 82 and 41 plants ha ${ }^{-1}$, after 5 years of implementation of the agroforestry system. 
Coffee cultivation in agroforestry system with Australian cedar, teak and African mahogany increases the organic matter and P content of the soil, but acidifies the soil and does not influence its physical attributes.

The agroforestry system with teak and African mahogany increases coffee yield.

\section{REFERENCES}

ARAÚJO, A. V. et al. Microclima e crescimento vegetativo do café conilon consorciado com bananeiras. Coffee Science, 10(2):214-222, 2015.

ARAÚJO, A. V. et al. Microclimate, development and productivity of robusta coffee shaded by rubber trees and at full sun. Revista Ciência Agronômica, 47(4):700-709, 2016.

BARBOSA, J. C.; MALDONADO JÚNIOR, W. Experimentação agronômica e AgroEstat: Sistema para análises estatísticas de ensaios agronômicos. Jaboticabal: Multipress, 2015. 396p.

BRAGA, M. M.; FURTINI NETO, A. E.; OLIVEIRA, A. H. Influência da saturação por bases na qualidade e crescimento de mudas de cedro-australiano (Toona ciliata M. Roem var. australis). Ciência Florestal, 25(1):49-58, 2015.

CARMO, D. L. et al. Chemical and physical attributes of a latosol and coffee crop nutrition in agroforestry and conventional management systems. Coffee Science, 9(1):122-131, 2014.

COELHO, R. A. et al. Nível de sombreamento, umidade do solo e morfologia do cafeeiro em sistemas agroflorestais. Revista Ceres, 57(1):95-102, 2010.

\section{COMISSÃO DE FERTILIDADE DO SOLO DO ESTADO} DE MINAS GERAIS - CFSEMG. Recomendações para o uso de corretivos e fertilizantes em Minas Gerais, $5^{\text {a }}$ aproximação. Viçosa: Ed. UFV, 1999. 359p.

\section{COMPANHIA NACIONAL DE ABASTECIMENTO -} CONAB. Acompanhamento da safra brasileira café safra 2019: Terceiro levantamento, setembro/2019. Brasília, 2019. 48p.

CRUZ, S. C. S. et al. Consórcio de milho e Brachiaria decumbens em diferentes preparos de solo. Acta Scientiarum Agronomy, 31(4):633-639, 2009.

DA MATTA, F. M.; RAMALHO, J. D. C. Impacts of drought and temperature stress on coffee physiology and production: A review. Brazilian Journal of Plant Physiology, 18(1):55-81, 2006.
DONAGEMA, G. K. Manual de métodos de análise de solos. Rio de Janeiro: Embrapa Solos, 2011. 230p.

GARCIA, R. A.; MARINONIO, G. B. Variação da cor da madeira de teca em função da densidade e do teor de extrativos. Floresta e Ambiente, 23(1):124-134, 2016.

GUARÇONI, A. M. Características da fertilidade do solo inuenciadas pelo plantio adensado de café conilon. Semina, 32(3):949-958, 2011.

GUIMARÃES, G. P. et al. Soil aggregation and organic carbon of oxisols under coffee in agroforestry systems. Revista Brasileira de Ciência do Solo, 38(1):278-287, 2014.

JARAMILLO-BOTERO, C.; MARTINEZ, H. E. P.; SANTOS, R. H. S. Características do café (Coffea arabica L.) sombreado no norte da América Latina e no Brasil: análise comparativa. Coffee Science, 1(2):94-102, 2006.

MAGALHÃES, S. S. A. et al. Estoque de nutrientes sob diferentes sistemas de uso do solo de Colorado do OesteRO. Acta Amazonica, 43(1):63-72, 2013.

MELLONI, R. et al. Sistemas agroflorestais cafeeiroaraucária e seu efeito na microbiota do solo e seus processos. Ciência Florestal, 28(2):784-795, 2018.

MORINIGO, K. P. G. et al. Efeitos da distribuição de árvores sobre atributos do solo em cafeeiro sombreado. Coffee Science, 12(4):515-525, 2017.

PARTELLI, F. L. et al. Microclimate and development of 'Conilon' coffee intercropped with rubber trees. Pesquisa Agropecuária Brasileira, 49(11):872-881, 2014.

PAVAN, M. A. et al. High coffee population density to improve fertility of an oxisol. Pesquisa Agropecuária Brasileira, 34(3):459-465, 1999.

PEZZOPANE, J. R. M. et al. Condições microclimáticas em cultivo de café conilon a pleno sol e arborizado com nogueira macadâmia. Ciência Rural, 40(6):1257-1263, 2010 .

PINTO NETO, J. N. et al. Efeito das variáveis ambientais na produção de café em um sistema agroflorestal. Coffee Science, 9(2):187-195, 2014.

RIBEIRO, A.; FERRAZ FILHO, A. C.; SCOLFORO, J. R. S. O cultivo do mogno africano (Khaya spp.) e o crescimento da atividade no Brasil. Floresta e Ambiente, 24:e00076814, 2017. 
SALGADO, B. G. et al. Avaliação da fertilidade dos solos de sistemas agroflorestais com cafeeiro (Coffea arabica L.) em Viçosa - MG. Revista Árvore, 30(3):343-349, 2006.

SILVA, F. C. Manual de análises químicas de solos, plantas e fertilizantes. 2.ed. rev.atual. Brasília: Embrapa Informação Tecnológica, 2009. 627p.
SOUZA, G. S. et al. Soil physico-hydraulic properties under organic conilon coffee intercropped with tree and fruit species. Pesquisa Agropecuária Brasileira, 52(7):539-547, 2017.

VALENTINI, L. S. P. et al. Temperatura do ar em sistemas de produção de café arábica em monocultivo e arborizados com seringueira e coqueiro-anão na região de Mococa, SP. Bragantia, 69(4):1005-1010, 2010. 